\title{
Generation of catalytic human Ago4 identifies structural elements important for RNA cleavage
}

\author{
JUDITH HAUPTMANN, ${ }^{1}$ LUKAS KATER, ${ }^{1}$ PATRICK LÖFFLER $^{2}{ }^{2}$ RAINER MERKL, ${ }^{2}$ and GUNTER MEISTER ${ }^{1}$ \\ ${ }^{1}$ Biochemistry Center Regensburg (BZR), Laboratory for RNA Biology, University of Regensburg, 93053 Regensburg, Germany \\ ${ }^{2}$ Institute of Biophysics and Physical Biochemistry, University of Regensburg, 93053 Regensburg, Germany
}

\begin{abstract}
Argonaute proteins bind small RNAs and mediate cleavage of complementary target RNAs. The human Argonaute protein Ago4 is catalytically inactive, although it is highly similar to catalytic Ago2. Here, we have generated Ago2-Ago4 chimeras and analyzed their cleavage activity in vitro. We identify several specific features that inactivate Ago4: the catalytic center, short sequence elements in the N-terminal domain, and an Ago4-specific insertion in the catalytic domain. In addition, we show that Ago2mediated cleavage of the noncanonical miR-451 precursor can be carried out by any catalytic human Ago protein. Finally, phylogenetic analyses establish evolutionary distances between the Ago proteins. Interestingly, these distances do not fully correlate with the structural changes inactivating them, suggesting functional adaptations of individual human Ago proteins.
\end{abstract}

Keywords: Argonaute proteins; Ago4; microRNAs; RNAi; siRNAs; gene silencing

\section{INTRODUCTION}

The Argonaute protein family is highly conserved across species, and its members directly interact with small regulatory RNAs such as microRNAs (miRNAs), short interfering RNAs (siRNAs), or Piwi interacting RNAs (piRNAs) (Hutvagner and Simard 2008; Meister 2013). Based on their amino acid sequences, Argonaute proteins can be grouped into the Ago clade (Ago proteins), the Piwi clade, and a worm-specific (WAGO) clade. While WAGO clade members have various different functions in worms (Yigit et al. 2006), the Piwi clade members are testes-specific and interact with piRNAs to repress transposable elements during spermatogenesis (Siomi et al. 2011). The Ago proteins are ubiquitously expressed and mainly bind miRNAs (Meister 2013).

All Argonaute proteins are characterized by a similar domain architecture composed of the $\mathrm{N}$ domain, the PIWIArgonaute-Zwille (PAZ) domain, the MID (middle domain), and the P-element-induced wimpy testes (PIWI) domain (Jinek and Doudna 2009). A short unstructured stretch of amino acids precedes the $\mathrm{N}$ domain, and flexible linkers connect both the N and PAZ as well as the PAZ and MID domains. The $\mathrm{N}$ domain appears to be involved in small RNA loading (Kwak and Tomari 2012), the PAZ domain anchors the $3^{\prime}$ end of the small RNA (Lingel et al. 2003; Song et al. 2003; Yan et al. 2003; Ma et al. 2004), and the MID domain the $5^{\prime}$ end ( $\mathrm{Ma}$ et al. 2005; Parker et al. 2005). The PIWI

Corresponding author: gunter.meister@vkl.uni-regensburg.de

Article published online ahead of print. Article and publication date are at http://www.rnajournal.org/cgi/doi/10.1261/rna.045203.114. domain is structurally similar to RNase $\mathrm{H}$, and indeed, some Argonaute proteins are endonucleases and cleave target RNAs that are fully complementary to the small RNA (Parker et al. 2004; Song et al. 2004). In human, the four Ago clade members (Ago1, 2, 3, and 4) are expressed, but only Ago2 is an active endonuclease (referred to as Slicer); and a catalytic tetrad within the PIWI domain is crucial for enzymatic activity (Liu et al. 2004; Meister et al. 2004; Nakanishi et al. 2012). In addition, we and others have recently shown that not only the PIWI domain but also the $\mathrm{N}$ domain contributes to slicer activity, presumably by helping to place the catalytic center and the target RNA in an ideal position to each other (Faehnle et al. 2013; Hauptmann et al. 2013; Nakanishi et al. 2013; Schürmann et al. 2013). In these studies, the activities of human Ago1, 2, and 3 have been compared. Ago4, however, has not been analyzed so far.

To complete the analysis of the cleavage activity of the human Ago proteins, we have performed swapping experiments between Ago 2 and Ago4. Using this approach, we succeeded to activate the slicer activity of Ago4. For activation of the Ago4 PIWI domain, we restored the catalytic tetrad and changed two short sequence elements. In order to activate full-length Ago4, we replaced two elements within the $\mathrm{N}$ domain by the Ago2 sequences. Surprisingly, phylogenetic clustering does not correlate with the observed numbers of sequence changes compared to active Ago2, thus suggesting

(C) 2014 Hauptmann et al. This article is distributed exclusively by the RNA Society for the first 12 months after the full-issue publication date (see http:// rnajournal.cshlp.org/site/misc/terms.xhtml). After 12 months, it is available under a Creative Commons License (Attribution-NonCommercial 4.0 International), as described at http://creativecommons.org/licenses/by-nc/4.0/. 
evolution-driven functional adaptations of individual Ago proteins.

\section{RESULTS AND DISCUSSION}

\section{Catalytic activation of the Ago4 PIWI domain}

The Ago4 PIWI domain lacks residues that are critical for cleavage activity (DEGR instead of DEDH). In order to unravel the structural basis for the cleavage incompetence of Ago4, we first investigated the Ago4 PIWI domain. To analyze the PIWI domain independently, we inserted it into the Ago2 backbone and reconstituted the DEDH motif, thus generating a presumably active catalytic center (Fig. 1A). The FLAG/HA-tagged protein was expressed in HEK 293 cells, immunoprecipitated, and used for in vitro cleavage of a radio labeled target RNA complementary to the endogenous miR-19b (Fig. 1B). However, the corrected catalytic center (Ago2-4 DEDH) did not show any cleavage activity,

A

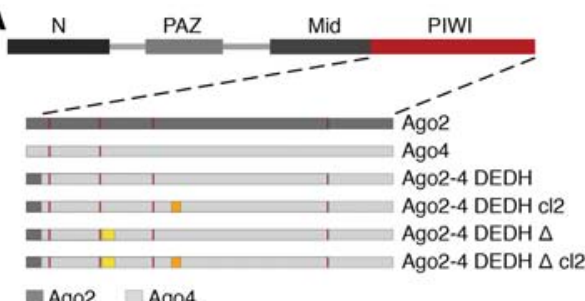

C

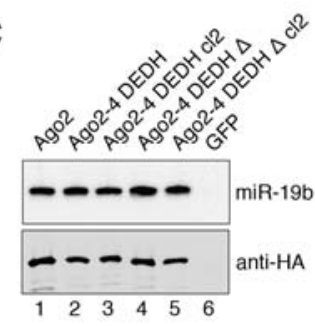

D

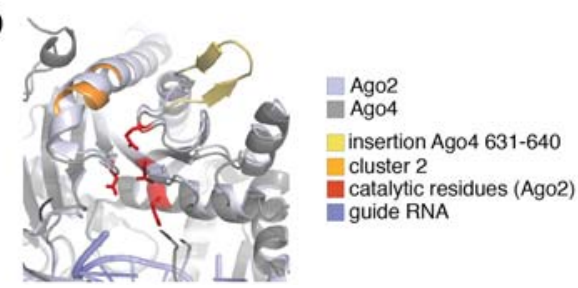

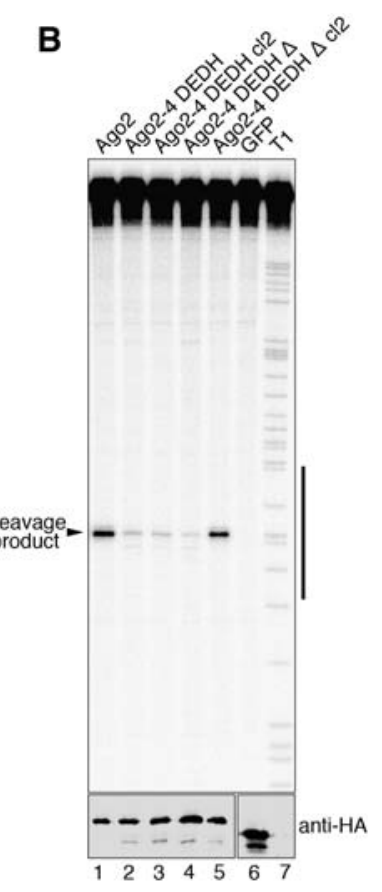

FIGURE 1. Several changes in the Ago4 PIWI domain activate its cleavage function. $(A)$ Schematic overview of the Ago domain organization and alterations applied to the Ago4 PIWI mutants: $(\mathrm{Cl} 2)$ adjustment of cluster 2 to the Ago2 sequence; $(\Delta)$ deletion of Ago4 631-640. (B) Cleavage assay of Ago2-4 PIWI mutants. F/H-tagged Ago constructs were expressed in HEK 293 cells, immunoprecipitated, and incubated with a radiolabeled target RNA complementary to endogenous miR-19b. The cleavage product is indicated by an arrowhead. "T1" is a partial digest of the target RNA with RNase T1. The region complementary to miR-19b is shown by a black bar. Western blots (lower panels) were included to control for efficient immunoprecipitation. (C) Northern blot of miR-19b coprecipitating with F/H-tagged Ago mutants. An anti-HA western blot demonstrates immunoprecipitation of equal amounts of $\mathrm{F} / \mathrm{H}$-Ago proteins. $(D) \mathrm{A}$ homology model of Ago4, modeled on the basis of the human Ago1 and Ago2 structures, illustrating the organization of the Ago4 (gray) catalytic center compared to Ago2 (light blue). indicating that additional structural variations exist in the Ago4 PIWI domain. In the Ago1 PIWI domain, a specific region (cluster 2; cl2), which influences the activity of the catalytic center, has been identified (Faehnle et al. 2013; Hauptmann et al. 2013; Nakanishi et al. 2013). Therefore, we swapped this cluster to the Ago2 version (Ago2-4 DEDH (Fig. 1A,B), but we did not observe significant cleavage Ago2 does not contain this insertion, we deleted it from Ago4 PIWI domain. Again, the deletion had no effect DH $\Delta$ ) (Fig. 1B). Strikingly, when both cluster 2 and (Fig. 1B). The observed changes in clevage activity are due to compromised small RNA binding since all mutants bound endogenous miR-19b with equal efficiency (Fig. 1C). Of note, faint bands that are occasionally observed with noncatalytic Ago versions are most likely due to background binding of endogenous Ago2. Taken together, we show that restoring the catalytic tetrad (Fig. 1D, red), swapping cluster 2 into the Ago2 sequence (orange), and mutating the Ago4-specific insertion (yellow) activates the PIWI domain of Ago4. The insertion is predicted to form two $\beta$ strands connected by an unstructured short loop. Interestingly, it is adjacent to residue E629 of the catalytic tetrad, which has recently been identified as the fourth catalytic residue. It is tempting to speculate that the Ago4-specific insertion might affect the position or flexibility of the E629 "glutamate finger" (Nakanishi et al. 2012; Sheng et al. 2014).

\section{Additional changes in the $\mathrm{N}$ domain are required for Ago4 cleavage}

We next asked whether the changes made to the PIWI domain are sufficient for cleavage activity in the Ago4 full-length context. However, although carrying the activated PIWI domain, Ago4 full length remained inactive (Ago4 PIWI+) (Fig. 2B). Since we had assigned a crucial role for cleavage to the $\mathrm{N}$ domain of Ago 1 and Ago3 (Hauptmann et al. 2013), we analyzed the Ago4 $\mathrm{N}$ domain in more detail. Swapping the Ago4 and Ago2 N domains restored cleavage activity of Ago4 carrying the activated PIWI domain, demonstrating that the remaining Ago4 
A

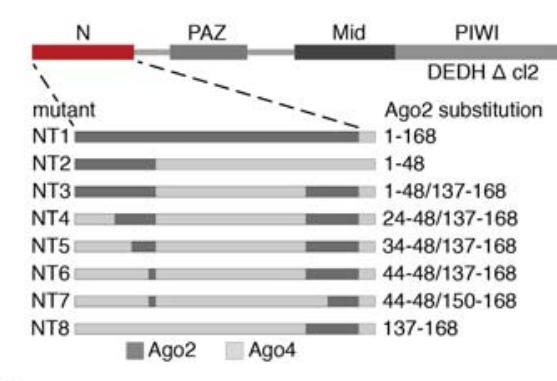

C

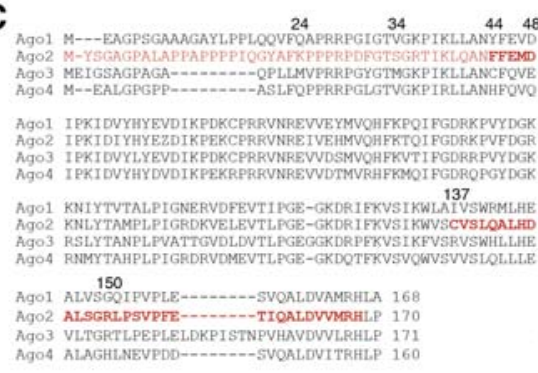

D

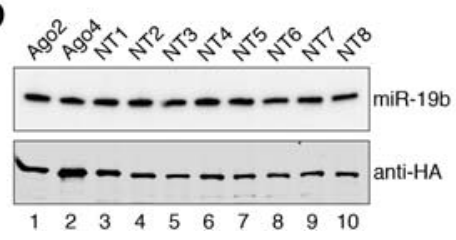

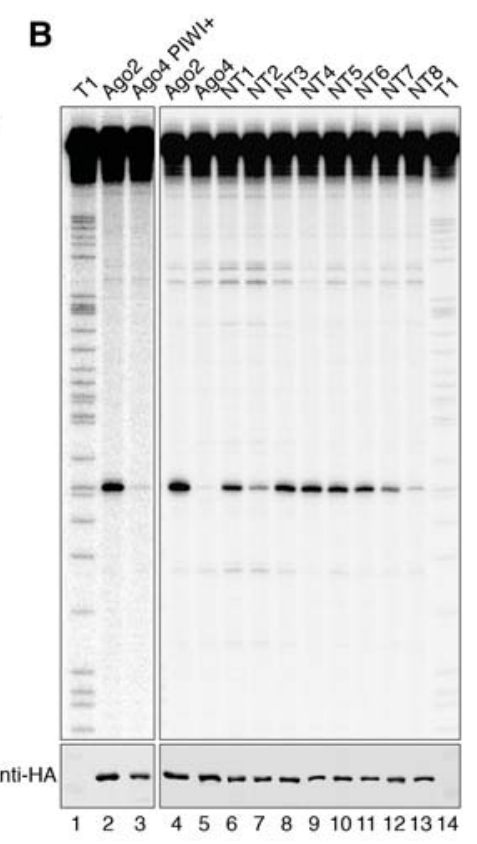

$\begin{array}{llllllllll}2 & 3 & 4 & 5 & 6 & 7 & 8 & 9 & 1011 & 121314\end{array}$

FIGURE 2. Additional alterations in two N-terminal regions generate a functional Ago4 slicer enzyme. (A) Schematic overview of the Ago4 domain organization and Ago2 substitutions applied to the Ago4 N-terminal mutants. (B) Cleavage assay and IP controls of Ago4 N-terminal mutants as described in Figure 1B. $(C)$ Alignment of the N-terminal sequences of Ago1-4. Substituted parts are indicated in red, and bold sequence parts represent minimal substitutions. Amino acid numbering follows the Ago2 sequence. (D) Analysis of mutant Ago4 miRNA binding by northern blot (upper). Loading of equal amounts of immunoprecipitated $\mathrm{F} / \mathrm{H}-\mathrm{Ago}$ was assessed by anti-HA western blotting (lower).

backbone does not affect cleavage (NT1) (Fig. 2A,B). In previous publications, we and others have found that two $\mathrm{N}$-terminal regions are critical for the activation of the PIWI domains of other noncatalytic Ago proteins (Faehnle et al. 2013; Hauptmann et al. 2013; Schürmann et al. 2013). In Agol, substitution of the absolute $\mathrm{N}$-terminal region was sufficient for cleavage activity (Hauptmann et al. 2013). Therefore, we swapped amino acids 1-48 of Ago4 to the Ago2 sequence, but this alteration was not sufficient for full activity although some activity was observed (NT2) (Fig. $2 \mathrm{~A}, \mathrm{~B}, \mathrm{C})$. In addition, a second region in the $\mathrm{N}$ domain was shown to affect cleavage activity, which we subsequently changed to Ago2 (Hauptmann et al. 2013; Schürmann et al. 2013). Although changing the second region alone resulted only in marginal cleavage activation (NT8) (Fig. 2A, $\mathrm{B})$, mutating both regions simultaneously resulted in full cleavage reconstitution (NT3). To further narrow down the responsible $\mathrm{N}$-terminal regions, we reduced the first sequence to the FFEMD motif that has been reported for Ago3 (Schürmann et al. 2013) and kept the second region constant (NT4-NT6). Indeed, this short motif is sufficient

for cleavage activity in combination with the second region. However, shortening of the second sequence reduced cleavage activity (NT7), suggesting that at least amino acids 137-150 contribute strongly to cleavage activity. Similar to the PIWI domain mutants, differences in activity were not due to differences in miR-19b loading (Fig. 2D).

\section{A cleavage-competent Ago protein is sufficient for miR-451 processing}

MiR-451 is a unique miRNA since it originates from a short hairpin that is not processed by Dicer. Instead, Ago2 cleaves the hairpin within the stem and thus loads mature miR-451 (Cheloufi et al. 2010; Cifuentes et al. 2010). Because Ago2 is the only active human Ago protein, miR-451 is exclusively found in Ago2 (Dueck et al. 2012). However, it is not clear whether only the catalytic activity or other Ago2-specific features are required for miR-451 generation. To address this question, we used $\mathrm{Ago}^{-/-}$ mouse embryonic fibroblasts (MEFs) and cotransfected a miR-451 expressing construct together with different human active and inactive Ago variants (Fig. 3; Hauptmann et al. 2013). As expected, wt Ago2 but not a catalytically inactive mutant (Ago2 DEDR) or wt Ago1, 3, or 4 can rescue miR-451 expression. Strikingly, all activated Ago versions (Ago1 cat, Ago3 cat, and Ago4 cat) rescue miR-451 processing, indicating that only a catalytically active Ago protein is required for miR-451

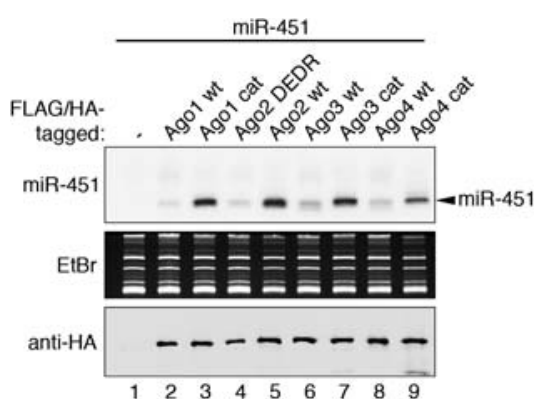

FIGURE 3. Ago requirement for miR-451 cleavage. Ago2-deficient MEFs were cotransfected with a pSUPER construct expressing miR451 and catalytically inactive (lanes $2,4,6,8$ ) or active (lanes $3,5,7,9$ ) Ago variants. miR-451 processing was assessed by northern blotting (upper). In lane 1, only miR-451 was transfected. For RNA quality and equal loading control, the gel was stained with ethidium bromide before blotting (middle). Ago expression levels were analyzed by antiFLAG IP followed by western blotting against the HA-tag (lower). 
expression (Fig. 3). Of note, background processing is observed with all catalytically inactive mutants but not when miR-451 is transfected alone (cf. lanes $1,2,4,6,8$ ), suggesting inefficient and artificial Ago binding followed by trimming of the miR-451 precursors under these conditions.

\section{Phylogenetic analysis of the four human Ago proteins}

Our comprehensive analysis of the cleavage activity of the human Ago clade members Ago1, Ago2, Ago3, and Ago4 revealed four distinct structural hotspots that influence cleavage activity (Fig. 4A). First, cleavage activity requires a complete catalytic tetrad composed of DEDH. This feature is present in Ago2 and Ago3 (Fig. 4A). Second, two structural elements within the $\mathrm{N}$ domain are also required for cleavage activity. While Ago1 only lost the first element, Ago3 and Ago4 lack both sequences, thus affecting cleavage activity of the PIWI domain (Fig. 4A, orange). Third, a short sequence

A
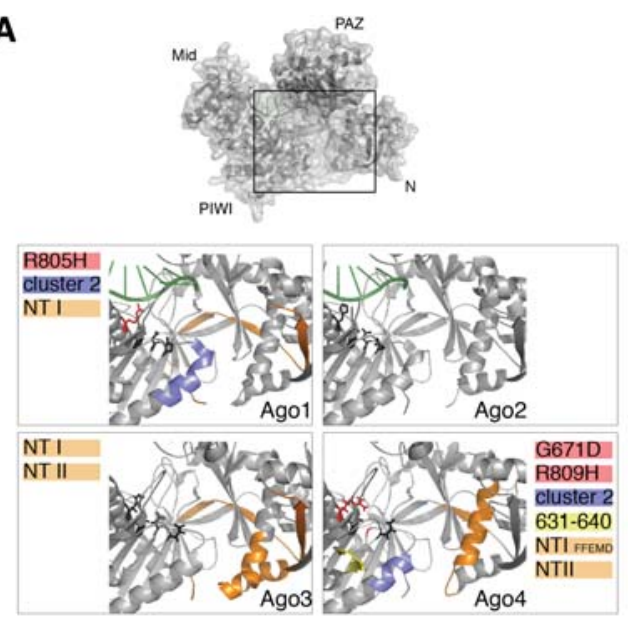

B

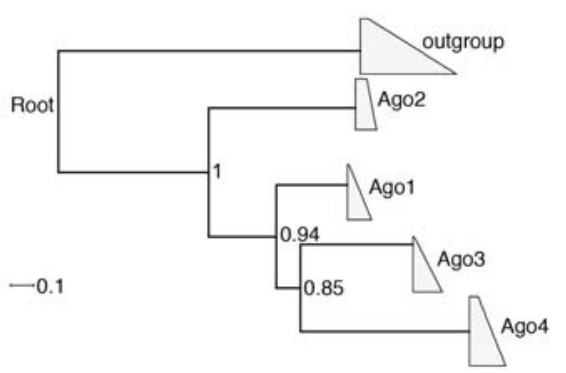

FIGURE 4. Cleavage-defining elements and phylogeny of human Ago1-4. (A) Overview of the four human Argonaute proteins and the alterations, which turned them into catalytically active enzymes. For Agol and Ago2, the X-ray structures (PDB IDs 4KXT and 4EI1) (Schirle and MacRae 2012; Nakanishi et al. 2013) are shown. Ago3 and Ago4 are depicted by homology models built on the published Ago1 and Ago2 structures. All changes needed to turn the individual Ago proteins into slicer enzymes are highlighted. The bound guide RNA is shown in green. (B) Phylogenetic analysis of Argonaute sequences from Chordata. Insect sequences served as an outgroup. Posterior probabilities of the tree branches indicate a high confidence level of the tree. Evolutionary distance is defined by the scale bar, which represents substitutions per site. Gray areas indicate a summary of closely related Ago amino acid sequences from different species. cluster in the PIWI domain (termed cluster 2) (Fig. 4A, blue) affects an $\alpha$-helix, which most likely leads to misorientation of the catalytic center. Fourth, Ago4 acquired a short insertion composed of two $\beta$-strands located close to the glutamate finger (E629) of the catalytic center (631-640) (Fig. $4 \mathrm{~A}$, yellow). Again, this insertion most likely misplaces active site amino acids leading to cleavage inactivity.

In order to understand the evolutionary relationship of the different human Ago clade proteins, we calculated a phylogenetic tree based on multiple Ago sequences from Chordata (Fig. 4B; Supplemental Fig. 1). Based on our biochemical analyses of slicer activities, we hypothesized that Ago3 might be evolutionarily closest to Ago2 followed by Ago 1 and Ago4. As expected, Ago2 is in an exceptional position and clusters apart from the other Ago proteins. Surprisingly, our phylogenetic tree reveals that Ago1 is more related to Ago2 than Ago3 to Ago2 (Fig. 4B), presumably suggesting Ago-specific functional adaptations independent of the catalytic activity. Our biochemical approaches together with the phylogenetic tree allows for several interesting speculations on the evolution of the human Ago clade members. First, all three noncatalytic Ago proteins contain a cleavage incompatible NTI sequence, suggesting that this might have been the first change that separated Ago 2 from the other three Ago proteins. Second, Ago3 and Ago 4 also contain cleavage incompatible NTII sequences, which could have been a second change that separated Ago1 from Ago3 and Ago4. This model would imply, however, that the cluster 2 mutations in Agol and Ago4 occurred independently of each other. Third and finally, active site mutations as well as the Ago4-specific insertion may have occurred after the separations.

\section{MATERIALS AND METHODS}

\section{Argonaute constructs}

FLAG- and HA-tagged human Ago2 and Ago4 as well as GFP were described earlier (Meister et al. 2004). To improve expression, all Ago4 sequences apart from the PIWI domain were cloned from a codon-optimized construct (Valdmanis et al. 2012).

Single amino acid changes were inserted by site-directed mutagenesis. Therefore, the whole plasmid was amplified with mutagenic primers, and template DNA was removed by $D p n$ I digestion.

The substitution of longer sequence stretches was achieved by generation of two PCR fragments that each carried the intended alterations at the central and a restriction site at the external end. The fragments were treated with NotI ( $5^{\prime}$ fragment) or EcoRI ( $3^{\prime}$ fragment), phosphorylated with PNK, and ligated into a dephosphorylated and NotI/EcoRI-digested vector (three-way blunt-end ligation).

For chimeric constructs, a terminal cloning primer and an internal chimeric primer were used to first amplify the shorter part of the construct from the first template. The resulting product and the other terminal cloning primer were used to amplify the second part of the construct from the second template.

Primer sequences for generation of the used Ago constructs are listed in Supplemental Table 1. 


\section{Cell culture, transfection, and cell lysis}

HEK 293 cells were cultured under standard conditions $\left(37^{\circ} \mathrm{C}, 5 \%\right.$ $\mathrm{CO}_{2}$ ) in Dulbecco's modified Eagle's medium (DMEM, Sigma) supplemented with 10\% FBS (Sigma) and penicillin-streptomycin.

Cells were grown on $15-\mathrm{cm}$ plates for cleavage assays. Per sample, one to two plates were calcium phosphate-transfected with $10 \mu \mathrm{g}$ plasmid DNA per plate. For miRNA binding assays, cells were grown on $10-\mathrm{cm}$ plates and transfected with $5 \mu \mathrm{g}$ plasmid DNA per plate.

Cells were harvested $24-48 \mathrm{~h}$ after transfection, washed with PBS once, and lysed in RIPA buffer (50 mM Tris/HCl pH 7.5, $150 \mathrm{mM}$ $\mathrm{NaCl}, 0.1 \%$ SDS, $1 \%$ sodium deoxycholate, $1 \%$ [v/v] NP-40, $1 \mathrm{mM}$ $\mathrm{NaF}, 1 \mathrm{mM}$ AEBSF, $0.5 \mathrm{mM}$ DTT). The lysates were incubated on ice for $20 \mathrm{~min}$ and cleared by centrifugation at $15,000 \mathrm{~g}$ for $20 \mathrm{~min}$ at $4^{\circ} \mathrm{C}$.

\section{In vitro Ago cleavage assays}

Preparation of the cap- ${ }^{32} \mathrm{P}$-labeled target RNA has been described before (Meister et al. 2004). Briefly, a perfectly complementary target RNA was in vitro transcribed from a PCR-amplified DNA template, purified on an $8 \%$ urea gel (UreaGel System, National Diagnostics), and gel-extracted. Approximately $1 \mu \mathrm{g}$ RNA was labeled in the presence of $20 \mu \mathrm{Ci} \alpha^{32}$ P-GTP, $25 \mu \mathrm{M}$ S-Adenosyl methionine, and guanylyltransferase. The product was again purified on an $8 \%$ urea gel, extracted, precipitated in ethanol, and solved in RNAse-free water.

Per cleavage sample, $25 \mu \mathrm{L}$ FLAG M2 agarose beads (SigmaAldrich, 50\% slurry) were washed with PBS twice. Lysates were added, and the samples were incubated for $3 \mathrm{~h}$ at $4^{\circ} \mathrm{C}$. Immunoprecipitates were washed four times with IP wash buffer (50 mM Tris/ $\mathrm{HCl} \mathrm{pH}$ 7.5, $300 \mathrm{mM} \mathrm{NaCl}, 5 \mathrm{mM} \mathrm{MgCl} 2,0.05 \%$ [v/v] NP-40, 1 $\mathrm{mM} \mathrm{NaF}$ ) and once with PBS. One fourth of each IP was used for western blot analysis. Therefore, $2 \times$ Laemmli Buffer was added, and the IPs were incubated for $5 \mathrm{~min}$ at $95^{\circ} \mathrm{C}$. A half volume of these samples was separated on $10 \%$ SDS-PAGE gels and semi-dry blotted onto an Amersham Hybond ECL nitrocellulose membrane (GE Healthcare). An anti-HA antibody (16B12, Covance, 1:1000) was used to detect IP efficiency of the overexpressed Ago proteins.

The remaining part of the IPs was used for Ago cleavage assays. Therefore, TM (3× TM: $200 \mathrm{mM} \mathrm{KCl,} 20 \mathrm{mM} \mathrm{MgCl}_{2}, 25 \mathrm{mM}$ DTT, 5 mM ATP; 1 mM GTP; $0.5 \mathrm{U} / \mu \mathrm{L}$ RiboLock RNase Inhibitor) was added together with $1-2 \mathrm{~Bq} / \mathrm{cm}^{2}$ of a cap- ${ }^{32} \mathrm{P}$-labeled target RNA complementary to miR-19b. Cleavage samples were incubated for $90 \mathrm{~min}$ at $30^{\circ} \mathrm{C}$. The reaction was stopped by addition of Proteinase $\mathrm{K}(0.4 \mu \mathrm{g} / \mu \mathrm{L}$ Proteinase K, $300 \mathrm{mM} \mathrm{NaCl}, 25 \mathrm{mM}$ EDTA, 2\% SDS, $200 \mathrm{mM}$ Tris $\mathrm{pH}$ 7.5). The RNA was extracted using aquaphenol/chloroform/isoamyl alcohol (25:24:1, Roth) and precipitated overnight with $20 \mu \mathrm{g}$ glycogen RNA grade (Fermentas). The resulting pellet was washed once with $70 \%$ ethanol. The RNA was solved in formamide loading dye and loaded onto an $8 \%$ sequencing gel (UreaGel System, National Diagnostics and Sequi-Gen Sequencing Cell, Bio-Rad). Gels were transferred onto Whatman filter papers, vacuum-dried, and exposed to a screen.

\section{miRNA binding assays and northern blotting}

FLAG-IPs and RNA extraction were conducted as described for cleavage assays. In contrast to cleavage assays, Proteinase K was add- ed directly after the IP washing steps. Total RNA was extracted and analyzed for coprecipitating miRNAs by northern blotting. Therefore, the RNA was separated on 12\% urea gels (UreaGel Systems, National Diagnostics) and semi-dry blotted onto an Amersham Hybond-N membrane (GE Healthcare). The membrane was EDC-crosslinked for $1 \mathrm{~h}$ at $50^{\circ} \mathrm{C}$ (Pall and Hamilton 2008) and prehybridized with hybridization solution $\left(5 \times \mathrm{SSC}, 20 \mathrm{mM} \mathrm{Na}_{2} \mathrm{HPO}_{4}\right.$ [pH 7.2], 7\% SDS, $1 \times$ Denhardt's solution). For miR-19b detection, 5'-TCAGTTTTGCATGGATTTGCACA-3' was used. Therefore, $20 \mathrm{pmol}$ of the DNA oligo were PNK-labeled with $20 \mu \mathrm{Ci} \gamma^{-32} \mathrm{P}-$ ATP. The probe was purified via a G-25 column (GE Healthcare) and incubated with the membrane in hybridization solution over night at $50^{\circ} \mathrm{C}$. Blots were washed twice with $5 \times$ SSC, $1 \%$ SDS, once with $1 \times$ SSC, $1 \%$ SDS, and wrapped in plastic wrap. Signals were detected by exposure to a screen and scanning with the PMI (Bio-Rad).

\section{MEF Ago2 ${ }^{-1-}$ rescues}

The pSUPER plasmid encoding miR-451 shRNA has been described before (Dueck et al. 2012). Ago1 and Ago3 minimal slicer constructs (Ago1 $\mathrm{N}_{1-64}$, Ago3 Mut5) and Ago1-4 codon-optimized sequences have also been described earlier (Valdmanis et al. 2012; Hauptmann et al. 2013). For Ago4 analysis, Ago4 NT6 (Fig. 2A) has been used. MEF Ago $2^{-/-}$cells (Liu et al. 2004) were cultured under standard conditions and seeded into six-well plates in antibiotics-free medium one day before transfection. Lipofectamine LTX and PLUS Reagent (Thermo Fisher Scientific) were used for transfection. Briefly, $2.5 \mu \mathrm{g}$ DNA $(2 \times 2.5 \mu \mathrm{g}$ DNA for cotransfections $)$ were diluted in $500 \mu \mathrm{L}$ Opti-MEM I Reduced Serum Medium, and $2.5 \mu \mathrm{L}$ PLUS Reagent were added and incubated for $5 \mathrm{~min}$. Per sample, 17.5 $\mu \mathrm{L}$ Lipofectamine LTX were added and incubated for $25 \mathrm{~min}$. The cell culture medium was changed before addition of the transfection solution. The cells were split to $10-\mathrm{cm}$ plates after $10 \mathrm{~h}$ and harvested after $48 \mathrm{~h}$. Total RNA was extracted from half the cells using TRIzol (Thermo Fisher Scientific). Per sample, $10 \mu \mathrm{g}$ total RNA were loaded to $12 \%$ urea gels for northern blotting. 5'-AACTC AGTAATGGTAACG-3' was used for miR-451 detection. The remaining cells were lysed in RIPA buffer and used for a FLAG-IP and western blotting.

\section{Homology models}

Homology models of Ago3 and Ago4 were built by using the standard homology modeling procedure of Yasara Structure (V 13.4.21) (Krieger et al. 2009). In short, initial 3D models were deduced from four, highly resolved 3D structures of Ago1 (PDB IDs: 4KRE, 4KXT) and Ago2 (PDB IDs: 4EI1, 4F3T), which served as templates (Jones 1999; Qiu and Elber 2006). Sequence identity as determined by NEEDLE (Rice et al. 2000) for targets and templates was at least $77 \%$, which is a value allowing for the computation of high quality models. Raw models were further refined by means of loop modeling and side-chain optimization using a combination of steepest descent and simulated annealing. Subsequently, the algorithm combined the best scoring fragments to deduce the final homology models, which after energy minimization, had a $Z$-score of -0.667 (Ago3) and -0.560 (Ago4); these values indicate good model quality. Homology models were analyzed and compared by using PyMol (http://www.pymol.org/). 


\section{Phylogenetic analyses}

Using human Ago1-4 sequences as query, homologs were collected by means of BLAST (Boratyn et al. 2013) and the NCBI nr database. Most similar hits were combined to a multiple sequence alignment (MSA) by means of Jalview (Waterhouse et al. 2009) and MAFFT (Katoh and Standley 2013). Identical sequences were removed by pairwise comparison. Among the remaining hits, 53 sequences, which represent a broad spectrum of Ago1-4 proteins in Chordata, were selected. In addition, 13 sequences of Argonautes or translation initiation factors from insects were chosen as an outgroup. Supplemental Table 2 lists the species names, protein functions, and acronyms used to label the tree.

Regions of uncertain alignment were removed from the MSA by means of GBLOCKS (V 0.91b) (Castresana 2000). A phylogenetic tree was computed by running eight chains of the Bayesian Monte Carlo Markov Chain (MCMC) sampler implemented in phylobayes/pb under the CAT model for 50,000 cycles (Lartillot et al. 2009). Then, a posterior consensus tree was deduced by means of phylobayes/readpb from the last 1000 cycles of the eight MCMCs. The tree depicted in Supplemental Figure 1 was plotted by means of Dendroscope (Huson et al. 2007).

\section{SUPPLEMENTAL MATERIAL}

Supplemental material is available for this article.

\section{ACKNOWLEDGMENTS}

We thank S. Ammon and C. Friederich for technical assistance; Dirk Grimm for codon-optimized Ago4; and Gregory Hannon for $\mathrm{Ago}^{-1-}$ MEFs. Our research is supported by grants from the Deutsche Forschungsgemeinschaft (SFB 960 projects B3 and B4 to G.M.); the European Research Council (ERC starting grant 242792 "sRNAs" to G.M.); the Bavarian Genome Research Network (BayGene to G.M.); and the Bavarian Systems-Biology Network (BioSysNet to G.M.).

Author contributions: J.H. and G.M. designed the experiments; J.H. and L.K. performed the experiments; R.M. and P.L. did phylogenetic analyses and structural modeling; and G.M. and J.H. wrote the manuscript.

Received March 12, 2014; accepted June 18, 2014.

\section{REFERENCES}

Boratyn GM, Camacho C, Cooper PS, Coulouris G, Fong A, Ma N, Madden TL, Matten WT, McGinnis SD, Merezhuk Y, et al. 2013. BLAST: a more efficient report with usability improvements. Nucleic Acids Res 41(Web Server issue): W29-W33.

Castresana J. 2000. Selection of conserved blocks from multiple alignments for their use in phylogenetic analysis. Mol Biol Evol 17: 540-552.

Cheloufi S, Dos Santos CO, Chong MM, Hannon GJ. 2010. A dicer-independent miRNA biogenesis pathway that requires Ago catalysis. Nature 465: 584-589.

Cifuentes D, Xue H, Taylor DW, Patnode H, Mishima Y, Cheloufi S, Ma E, Mane S, Hannon GJ, Lawson ND, et al. 2010. A novel miRNA processing pathway independent of Dicer requires Argonaute2 catalytic activity. Science 328: 1694-1698.

Dueck A, Ziegler C, Eichner A, Berezikov E, Meister G. 2012. microRNAs associated with the different human Argonaute proteins. Nucleic Acids Res 40: 9850-9862.
Faehnle CR, Elkayam E, Haase AD, Hannon GJ, Joshua-Tor L. 2013. The making of a slicer: activation of human Argonaute-1. Cell Rep 3: 1901-1909.

Hauptmann J, Dueck A, Harlander S, Pfaff J, Merkl R, Meister G. 2013. Turning catalytically inactive human Argonaute proteins into active slicer enzymes. Nat Struct Mol Biol 20: 814-817.

Huson DH, Richter DC, Rausch C, Dezulian T, Franz M, Rupp R. 2007. Dendroscope: an interactive viewer for large phylogenetic trees. BMC Bioinformatics 8: 460.

Hutvagner G, Simard MJ. 2008. Argonaute proteins: key players in RNA silencing. Nat Rev Mol Cell Biol 9: 22-32.

Jinek M, Doudna JA. 2009. A three-dimensional view of the molecular machinery of RNA interference. Nature 457: 405-412.

Jones DT. 1999. Protein secondary structure prediction based on position-specific scoring matrices. J Mol Biol 292: 195-202.

Katoh K, Standley DM. 2013. MAFFT multiple sequence alignment software version 7: improvements in performance and usability. Mol Biol Evol 30: 772-780.

Krieger E, Joo K, Lee J, Raman S, Thompson J, Tyka M, Baker D, Karplus K. 2009. Improving physical realism, stereochemistry, and side-chain accuracy in homology modeling: four approaches that performed well in CASP8. Proteins 77 Suppl 9: 114-122.

Kwak PB, Tomari Y. 2012. The N domain of Argonaute drives duplex unwinding during RISC assembly. Nat Struct Mol Biol 19: $145-151$.

Lartillot N, Lepage T, Blanquart S. 2009. PhyloBayes 3: a Bayesian software package for phylogenetic reconstruction and molecular dating. Bioinformatics 25: 2286-2288.

Lingel A, Simon B, Izaurralde E, Sattler M. 2003. Structure and nucleicacid binding of the Drosophila Argonaute 2 PAZ domain. Nature 426: 465-469.

Liu J, Carmell MA, Rivas FV, Marsden CG, Thomson JM, Song JJ, Hammond SM, Joshua-Tor L, Hannon GJ. 2004. Argonaute2 is the catalytic engine of mammalian RNAi. Science 305: 1437-1441.

Ma JB, Ye K, Patel DJ. 2004. Structural basis for overhang-specific small interfering RNA recognition by the PAZ domain. Nature 429: 318-322.

Ma JB, Yuan YR, Meister G, Pei Y, Tuschl T, Patel DJ. 2005. Structural basis for $5^{\prime}$-end-specific recognition of guide RNA by the A. fulgidus Piwi protein. Nature 434: 666-670.

Meister G. 2013. Argonaute proteins: functional insights and emerging roles. Nat Rev Genet 14: 447-459.

Meister G, Landthaler M, Patkaniowska A, Dorsett Y, Teng G, Tuschl T. 2004. Human Argonaute 2 mediates RNA cleavage targeted by miRNAs and siRNAs. Mol Cell 15: 185-197.

Nakanishi K, Weinberg DE, Bartel DP, Patel DJ. 2012. Structure of yeast Argonaute with guide RNA. Nature 486: 368-374.

Nakanishi K, Ascano M, Gogakos T, Ishibe-Murakami S, Serganov AA, Briskin D, Morozov P, Tuschl T, Patel DJ. 2013. Eukaryote-specific insertion elements control human ARGONAUTE slicer activity. Cell Rep 3: 1893-1900.

Pall GS, Hamilton AJ. 2008. Improved northern blot method for enhanced detection of small RNA. Nat Protoc 3: 1077-1084.

Parker JS, Roe SM, Barford D. 2004. Crystal structure of a PIWI protein suggests mechanisms for siRNA recognition and slicer activity. EMBO J 23: 4727-4737.

Parker JS, Roe SM, Barford D. 2005. Structural insights into mRNA recognition from a PIWI domain-siRNA guide complex. Nature 434: 663-666.

Qiu J, Elber R. 2006. SSALN: an alignment algorithm using structuredependent substitution matrices and gap penalties learned from structurally aligned protein pairs. Proteins 62: 881-891.

Rice P, Longden I, Bleasby A. 2000. EMBOSS: the European Molecular Biology Open Software Suite. Trends Genet 16: 276-277.

Schirle NT, MacRae IJ. 2012. The crystal structure of human Argonaute2. Science 336: 1037-1040.

Schürmann N, Trabuco LG, Bender C, Russell RB, Grimm D. 2013. Molecular dissection of human Argonaute proteins by DNA shuffling. Nat Struct Mol Biol 20: 818-826. 
Sheng G, Zhao H, Wang J, Rao Y, Tian W, Swarts DC, van der Oost J, Patel DJ, Wang Y. 2014. Structure-based cleavage mechanism of Thermus thermophilus Argonaute DNA guide strand-mediated DNA target cleavage. Proc Natl Acad Sci 111: 652-657.

Siomi MC, Sato K, Pezic D, Aravin AA. 2011. PIWI-interacting small RNAs: the vanguard of genome defence. Nat Rev Mol Cell Biol 12: 246-258.

Song JJ, Liu J, Tolia NH, Schneiderman J, Smith SK, Martienssen RA, Hannon GJ, Joshua-Tor L. 2003. The crystal structure of the Argonaute2 PAZ domain reveals an RNA binding motif in RNAi effector complexes. Nat Struct Biol 10: 1026-1032.

Song JJ, Smith SK, Hannon GJ, Joshua-Tor L. 2004. Crystal structure of Argonaute and its implications for RISC slicer activity. Science 305: 1434-1437.
Valdmanis PN, Gu S, Schüermann N, Sethupathy P, Grimm D, Kay MA. 2012. Expression determinants of mammalian argonaute proteins in mediating gene silencing. Nucleic Acids Res 40: 37043713.

Waterhouse AM, Procter JB, Martin DM, Clamp M, Barton GJ. 2009. Jalview Version 2-a multiple sequence alignment editor and analysis workbench. Bioinformatics 25: 1189-1191.

Yan KS, Yan S, Farooq A, Han A, Zeng L, Zhou MM. 2003. Structure and conserved RNA binding of the PAZ domain. Nature 426: 468-474.

Yigit E, Batista PJ, Bei Y, Pang KM, Chen CC, Tolia NH, Joshua-Tor L, Mitani S, Simard MJ, Mello CC. 2006. Analysis of the C. elegans Argonaute family reveals that distinct Argonautes act sequentially during RNAi. Cell 127: 747-757. 

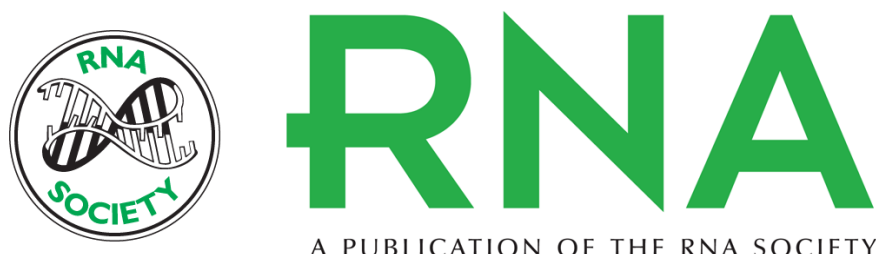

A PUBLICATION OF THE RNA SOCIETY

\title{
Generation of catalytic human Ago4 identifies structural elements important for RNA cleavage
}

Judith Hauptmann, Lukas Kater, Patrick Löffler, et al.

RNA 2014 20: 1532-1538 originally published online August 11, 2014

Access the most recent version at doi:10.1261/rna.045203.114

\begin{abstract}
Supplemental http://rnajournal.cshlp.org/content/suppl/2014/08/04/rna.045203.114.DC1
Material

References This article cites 38 articles, 6 of which can be accessed free at:

http://rnajournal.cshlp.org/content/20/10/1532.full.html\#ref-list-1

Creative This article is distributed exclusively by the RNA Society for the first 12 months after the Commons full-issue publication date (see http://rnajournal.cshlp.org/site/misc/terms.xhtml). After 12 License months, it is available under a Creative Commons License (Attribution-NonCommercial 4.0 International), as described at http://creativecommons.org/licenses/by-nc/4.0/.
\end{abstract}

Email Alerting Receive free email alerts when new articles cite this article - sign up in the box at the top Service right corner of the article or click here.

To subscribe to RNA go to:

http://rnajournal.cshlp.org/subscriptions 